\title{
Education and Healthcare Reforms in Post- Conflict Setting: Case Studies in Kosovo
}

\author{
Alex E Han \\ Independent Researcher, Chadwick International, SOUTH KOREA
}

ISSN: 2311-8636 (Print)

ISSN: 2312-2021 (Online)

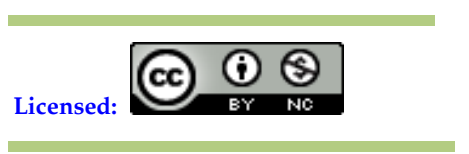

Source of Support: Nil

No Conflict of Interest: Declared

*Email for correspondence:

alexjiyoonhan@gmail.com

\section{ABSTRACT}

Kosovo is a small country that was first declared an independent state on 17 February 2008. Albanians make up $90 \%$ of the overall population, whereas the Serbs, Turks, Bosnians, and Roma make up to $10 \%$ of the total population as the minority group. Before 1999, Kosovo was part of the Yugoslav organization, but after the March -June 1999 conflicts, the North Atlantic Treaty Forces (NATO), thus bringing Kosovo under United Nations administration (Solana, 114-120). Post-conflict recovery is heavy for Kosovo as it entails rebuilding numerous systems' infrastructure for both the healthcare system and education system (Solana, 114-120). The infrastructure and procedures need to be carefully reorganized to curb both communicable and noncommunicable diseases to restructure family care and also to better the education provided in Kosovo. The new state is experiencing a slow economic growth rate of less than $4 \%$ causing a slow growth rate of both the education and the healthcare system. This rate of economic growth is caused by almost half of the Kosovo people being unemployed and young. The state of the education system in Kosovo has been affected by many different players that have over the years disintegrated the education system and particularly left adverse effects on children and women. According to the PISA international exam for international students OECD exam that was conducted to test the ability of learners to study, Kosovo students became the last three position out of the 73 counties that took the test for math and reading. This shows that the quality of education at these schools is still low. This indicated poor planning in the Kosovo education system for instance the high congestion in schools since due to the overcrowding, students do not get to experience the personalized teaching they require hence both the learners and teachers end up feeling stressed, poor funding for schools in Kosovo, poor working standards and low salaries for teachers. These reforms were to help Albania to reform from the adverse effects of conflict by the Serbians. The aim of these reforms for both healthcare and education was to improve the current unfavorable conditions like lack of equipment as the learners would sit on the floor and write on each other's backs and hospitals lacked equipment for work.

Keywords: Kosovo, Conflict, Reorganization, Reform, Education, Healthcare

\section{INTRODUCTION}

Conflict refers to a clash or a variance of opinions between two entities. Post-conflict, millions of people were dead and others became homeless. Looking at the Kosovo conflict, it led to the collapse of the European economy, and the destruction of the industrial infrastructure. The Soviet Union was also heavily affected with a number of long-term social 
consequences. Innocent civilians like children and women were affected due to lack of proper education. Proper education, health and housing as these are not on the top of the list in the government's radar during war. Kosovo's healthcare program was historically part of Yugoslav Healthcare. However, the late-twentieth-century disintegration of the state led to a standstill in Kosovo. The larger area of Kosovo is unconsolidated, and the more significant part of the healthcare legislation is non-existent in short. Even though Kosovo has made progress in many other systems, the health sphere is yet to reach the level that other European countries are now. This essay aims to describe the complexity of the situation that the Healthcare and educational situation in Kosovo faces currently as it has been 12 years since the transfer of competencies from global administrators to the local authorities and post 1999 war conflict while incorporating the historical flow of events and any strategic planning of the healthcare system since.

\section{How the Kosovo conflict IMPACTED the EDUCATION SYSTEM IN Kosovo}

Kosovo, located in the Balkan Peninsula in Europe, is a region of long-lived ethnic conflict between ethnic Serbs and ethnic Albanians. More than $90 \%$ of the people in Kosovo are ethnic Albanians, while approximately $8 \%$ are ethnic Serbs, and the rest are other ethnic groups such as Bosnian Muslims (World Book, 2020). Kosovo was a province of Serbia, which was part of a federated union called Yugoslavia after World War II. In 1974, the Yugoslav constitution recognized the autonomy of Kosovo, allowing it to act as an independent government. However, because Kosovo was an area historically sacred to ethnic Serbs, Serbians had always opposed about how Muslim Albanians held authority over Kosovo.

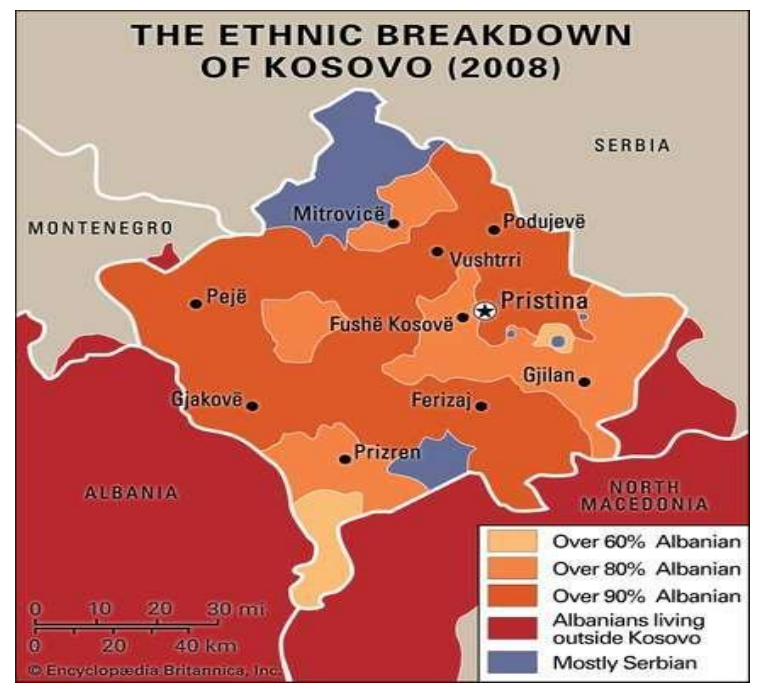

Figure 1: Kosovo: ethnic

Then, in 1989, Solobdan Milosevic, the president of the Serbian republic at that time, stripped the constitutional freedom away from Kosovo and oppressed ethnic Albanians using military force. Radical groups that wanted independence from Serbia formed the Kosovo Liberation Army (KLA) in 1996 and launched violent attacks on Serbin police and politicians. In 1998, open conflict broke out as the Serbian government responded with a crackdown on the Albanians in the area. The conflict ended in June 1999, with the North 
Atlantic Treaty Organization's (NATO) intervention (Britannica, 2020). After the conflict, aspects of the Kosovar society went through rapid and radical change. In Kosovo today, more than $90 \%$ of the people in Kosovo are of Albanian ethnicity, while approximately $8 \%$ are of the Serb decentry. The other smaller minority group comprises of Bosnian Muslims.

\section{Education system}

The education system in Kosovo, in particular, benefited after the Kosovo conflict from relieved oppression of Albanian people, the establishment of the New Kosovo Curriculum Framework (KCF) in 2001, and the Kosovo Educator Development Program (KEDP).

After the Kosovo conflict, oppression on Albanian education was lifted, and the Albanians did not have to hide in a parallel, underground system.

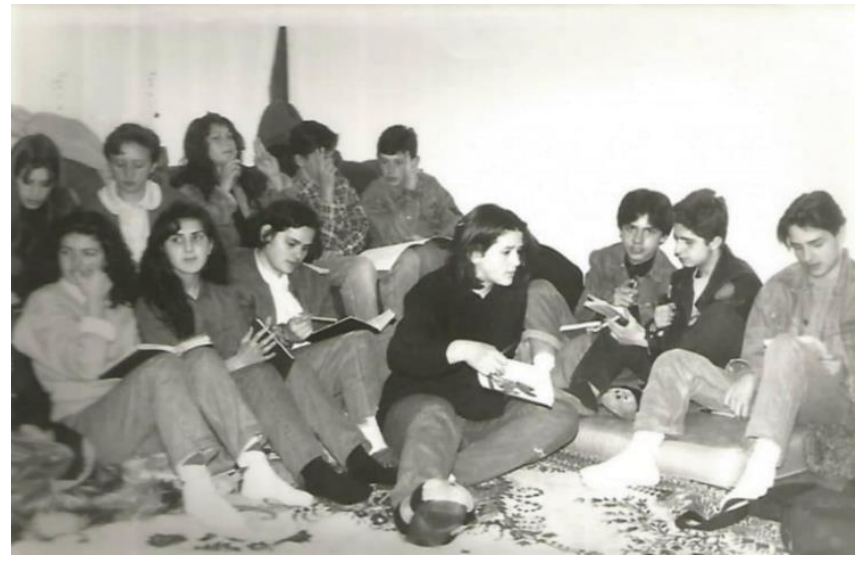

Figure 2: Kosovo Albanian students at the Xhevdet Doda high school at a home-school class in Pristina (BalkanInsights, 2019)

During 1990s, Albanian students could not attend official schools in a house-school in Kosovo. Until 1992, Serbian children and Albanian children in Kosovo attended integrated schools without division. However, after Milsovenic came into power, all schools were forced to use the Serbian curricula, and Albanians were not even allowed to enter school buildings. Albanian families would devote their homes to use as schools, as shown in figure 2. Children would sit on the floor, write on each others' backs, and hide from the Serbian police. If the Serbian police found an Albanian student suspected to attend such schools, they would physically abuse the student and tear all the notebooks and textbooks they carry.

As such, prior to the 1998-1999 conflict, there existed a parallel existence between the official, Serbian curriculum offered only to Serbs and the unofficial education system that Albanians attended (Llapi). After the Kosovo conflict, however, the systematic repression upon Albanian education was relieved, and there were no longer fears relating to such ethnic exclusion. Students could attend official schools in school buildings with approved curricula taught in Albanian. They were granted with longer class hours and necessary learning equipment, such as large classrooms, labs, desks and chairs. Although there are still challenges including costs of schooling, outdated textbooks and a lack of facilities, the basis for further development was achieved after the conflict lifted the strict ban on Albanian education. 
Education in Kosovo was further developed with the establishment of the New Kosovo Curriculum Framework (KCF) in 2001. According to the Curriculum Framework for preuniversity education in Kosovo, "The Curriculum Framework sets forth the foundations for quality enhancement and equal educational provision for all students, as well as the relationship between the Kosovo education system and current educational reforms taking place in the most developed education system" (Mustafa, 2011). This quote indicates the importance of the establishment of a new Curriculum Framework, which was the stepping stone for additional reform and policy development. The United Nations formed an administration, the United Nations Mission in Kosovo (UNMIK). The UNMIK and the United Nations Children's Fund (UNICEF) together established the KCF through analyzing the urgent problems in the Kosovar education system that had to be addressed. The KCF aimed to shift the purpose of learning from mere delivery of knowledge to developing values and critical thinking skills through learner-centered education. With this goal, the KCF provided a guideline for educational reform and policies in Kosovo through setting specific outcome goals and requirements for preschool, primary and secondary education and standardizing education levels with other European countries. Proposals included lowering the mandatory school entrance age from 7 to 6 , setting common requirements for all students and creating common subject time tables for compulsory subjects. The KCF was the groundwork for setting goals for future educational reform, thus benefiting the Kosovo education system.

Another way the Kosovo education system was improved after the Kosovo conflict was through the Kosovo Educator Development Program (KEDP). In 2001, right after the conflict, the Transitional Administrative Department of Education, Science and Technology (TA-DEST) estimated that 2 out of 5 teachers lack appropriate education or professional training. However, from 2012 to 2017 , up to $96 \%$ of the teachers have received training and been awarded with career licenses (European Union). This indicates a significant increase in the percentage of trained, licensed teachers leading to the improvement of educational quality. During the 1990s, Albanian teachers had no access to official training, and could not improve and absorb new teaching methods. Most of the teachers that taught Albanian students at house-schools were not professionally trained, and because of this, the teaching was highly based on factology, which put little focus on understanding ideas and creative thinking. However, teaching is an influential part of youth development, and especially for young students, teachers play a crucial role in both academics and social skills. Thus, teacher training was an urgent issue in Kosovo.

The Canadian International Development Agency (CIDA) sponsored the Kosovo Educator Development Program (KEDP), which provided professional training to Albanian teachers about teaching techniques and encouraging students to enjoy learning. The program also trained school directors and officials on management and conduct. Improved teacher training and stricter teaching license regulations increased the quality of education for Kosovar students (Pupovci, 2013). Therefore, the renewed focus and push for educational development from international organizations helped in carrying out reform policies and training programs in order to improve the education system in Kosovo.

There are still problems with creating an integrated education system between different ethnic groups; nevertheless, as a result of the Kosovo conflict, the Kosovo education system could benefit from the lifted oppression on Albanian people and new educational reform policies such as the New Kosovo Curriculum Framework and Kosovo Educator Development Program. Education is a crucial value because it is the basis of social, economic 
and political development, allowing people to empower themselves. Taking away education from an ethnic group takes away their opportunity to learn how to represent and protect themselves, therefore their chance to grow. Although the open conflict that killed more than 13,000 people and destroyed most of the infrastructure in Kosovo was devastating, it also opened opportunities for Albanians to develop their identity and accumulate knowledge by improving education (Plesch, 2015).

\section{How the Kosovo Conflict Affected the Healthcare System}

The health recovery path would take long, especially when reviving the medical and nursing education systems (Hossen et al., 2021). Today, almost one in every three Kosovars has been reported to find the healthcare system unaffordable. The Kosovar healthcare system deteriorated fast due to Serbia's 'apartheid system' for over ten years. The country was integrated into the Serbia healthcare system up to the year 1999. However, since Kosovo gained its independence, there was a need for creating reforms in the Healthcare System to improve certain critical areas of the health provision system (Buwa et al., 226-330). This initiative looked promising especially considering the enthusiasm of the Kosovars and the promise they received that they would get international support. However, the Kosovar healthcare system has faced several challenges during the reforms, leading to the slow consolidation and reorganization of the Kosovo Healthcare System.

Currently, the new healthcare implementation system looks promising as there is some progress in the implemented reforms; however, much remains undone to reach the same level as other European countries. The Albanian Kosovars used the clandestine healthcare system during the war, also known as the Mother Theresa Organization. On the other hand, the Serbs have a healthcare system of their own, showing how the segregated system still has unresolved ethnic gaps that would bring tension to minorities like the Roma, Turkish, Gorani, Egyptians, Bosniaks, and Arshkali, who until today suffer from ethnicity biases and poverty. Statistics from UNICEF showed that the rate of deaths for every 1,000 births is estimated to be between as high as 18-44,6.75 for Serbia, and 9.1 for Bosnia. The Kosovo government also reports a high maternal mortality rate of 12 and 23 for every 100,000 in 2005.

\section{The health system in Kosovo}

Before the Serbian apartheid, the Yugoslavian health system was relatively well organized compared to other health systems for other European countries (European Union, pp. 9-9). However, the dissolution of the countries and the ten years in the 'parallel system' (the war inflicted system between1990 -1999) has resulted in the deterioration of health status. The plan was organized in a humanitarian association from the "Mother Teresa" foundation. Healthcare today is administered in three levels; primary, secondary, and tertiary. Direct services are covered by 33 municipal administrative units that offer Family Health Centers. Secondary healthcare services are provided at the Prishtina University Hospital, five regional and four city hospitals. Finally, the tertiary services, mainly specialized, are offered through health institutions provided by Prishtina University with the University Clinical Center of Kosovo (Nietsch, 220-256).

In Kosovo, family care is not as highly recognized as a noble career; hence only a few physicians and a few medical students consider involving themselves in this career path. The European-sponsored training program was preceded by a more efficient Ministry of Health $(\mathrm{MoH})$ training that supported family care medicine. Physicians working in the public sector earn a low wage of about 300-450 Euros each month. The healthcare system in 
Kosovo, like other systems, is facing a change in reforms. The "fulcrum for change" movement was, however, been plagued with several challenges.

The restructuring and growth of the health system since post-conflict Kosovo has seen a number of structural changes, reorganization of reforms and also a number of challenges. The transfer of responsibilities from UNMIK to the current Ministry of Health is due to the structural adjustments since 1999. United Nations and the local Kosovars jointly administer the Department of Health and Social Welfare due to the Joint-Interim-AdministrativeStructures (Buwa et al., 226-330). The elected minister Permanent Secretary issued between 13 September 13th September 2001 to 03 March 2002 due to the delay of the 'Provisional Self-Governing Institutions' (PSGI) Ministry of Health, Environment and Spatial Planning (Steinhubl et al, 2395-2396). The management of the health sector in Kosovo was led by a local Minister and Permanent Secretary following the general policies of the ruling government.

The Healthcare policies and systematic reforms in Kosovo after the end of the conflict, led the World Health Organization and national experts to draft the 'Health Strategy for Kosovo.' This strategic document was approved by September 1999 to find stability for the health sector. 2010 - 2014 marked a period of reforms formation that aimed to guide development in the Kosovo Health System in alignment with the government planning. The WHO was one of the bodies that led to the post-conflict initiation of Kosovo (European Union, pp. 9-9). Some of the Healthcare reforms created in 1999 are still being applied today. The healthcare development and restructuring involved reforms in the Health Care legal framework, the restructuring, reorganization, and completion of the Health Care infrastructure, the restructuring of the Medical equipment in accordance to the European standards, plans for developing and enhancement of 'family healthcare' as the core pillar of primary care in Kosovo, the development of a professional and leadership system within the health institutions, development of the Information System in the healthcare system and establishing ways of adequately funding the Healthcare system in Kosovo (Buwa et al., 226330). The healthcare system today in Kosovo comprises of a legal framework for Healthcare in Kosovo has been shaped by the reforms and standards. The laws that govern the healthcare system are designed by both the local and international in Kosovo.

Currently, the Kosovar healthcare system and infrastructure are undergoing a number reorganization and implementations. The current health sector has indicated a gap in the new integrated health care plan; thus, there is a need to reorganize services in the health care, professional human resources, and medical equipment (Shuey, 299-310). There was also a deficiency in a master plan for staffing healthcare services, leading to a more uncoordinated health system in Kosovo. The developmental process of the 'Patient Care' of the Kosovo Healthcare system is being met by international support. For instance, the concept of 'Family Healthcare' after the 1999 war is the pivot of Kosovo's Healthcare. The department of FMDC administered it and with the support of the "Royal College of General Practitioners" (UK) (European Union, pp. 9-9). The management of family health care from the municipalities of Kosovo involves the organization of the healthcare services in Kosovo that are made based on successfully decentralizing the financial budget.

Despite the massive growth in the healthcare system, the Kosovo health care system needs reforms in the managerial and financial sections to improve coordination in the system's functioning. For instance, the 'system of reference' lacks coordination, whereas the Tertiary (THC) and Secondary Health Care (SHC) are overloaded. Professionals' motivation is also essential, primarily because of the low income (Shuey, 299-310). 
Another aspect of the developmental process of the healthcare system in Kosovo involves how the Ministry of Health and the Public Institute of Health drafted a document known as "Strategy for Health Information System" that summarizes the vision, principles, goals, and objectives for the health sector in Kosovo. However, the document lacks proper coordinated data of the public, private, and sectors.

In Kosovo, there is need for a proper funding system. Generally, Kosovo operates with minimum funds allocated in the budget to cater for healthcare. The investments in health care are minimal, mainly because of the unprioritized Healthcare in post-conflict Kosovo, especially by changing governments. The Finance Ministry manages health financing; however, its involvement in the Ministry of Health has been very limited in the past (Steinhubl et al, 2395-2396). The Insurance Fund is sustainable if a sustainable method of funding and health insurance is implemented, is only to prove that those critical issues have never been set up as a concrete priority within the plan of any changing Kosovo governments.

The consolidation of the healthcare system after the conflict in the twelve years post-conflict, Kosovo's Healthcare System has created a legislative basis in line with the European standards. However, the concept of Family Healthcare is slowly finding its meaning with the Kosovar population and being understood and accepted by most health professionals. Political influence on the healthcare system within the Kosovo Health Ministry is also a very acute issue that needs to be addressed. Political influence currently negatively influences the fragile health system.

\section{Discussion}

The Kosovo government was declared a new state in 2008. As an upcoming state, the slow economic growth rate of less than $4 \%$ in 2006 with an unemployment rate of up to $45 \%$, making the country the poorest country in Europe (European Union, pp. 9-9). However, Kosovo's plans and programs. War has adverse effects on people's psychological well-being (Cardozo, 569-600). The trace elements of war are long present even long after the war is done. Some of the effects that have been experienced are displacement, destruction of property, death and deterioration of the economy. All these effects have negative impacts on economic growth hence negatively impacting education and healthcare systems development. With the presence of war, forward progression is entirely impossible. A good example is that war brings stress on both the children and adults and it denies them peace of mind to stay in a classroom and learn.

A good example is the Kosovar education system today which still is recuperating from the adverse effects of the war. The Education systems suffer from a lack of infrastructures like proper schools with seats, tables and other tools like a board and learning facilities like books updated with the new syllabus. The Kosovar student lacked these facilities and would use outdated books and write on each other's backs. With these aspects, education cannot thrive in the aforementioned locations. It would be difficult to maintain a good education system without harmony, peace and governmental guidance. In the healthcare system, after independence and separation from Serbia, the healthcare system in Kosovo had to be quickly implemented and the correct reforms to be put in place. Earlier the Kosovo's people were dependent on Mother Teresa's foundations (Nietsch, 200-256). A new healthcare system with the current state of affairs especially with the slow economic growth is difficult. Healthcare reforms need restructuring of the available infrastructure and legislative 
guidelines (Ragi et al., 2021). With the low financial support healthcare just like education is experiencing a very slow growth rate.

\section{CONCLUSION}

Summarily, after the conflict, there was a push for the reorganization of the Healthcare System in Kosovo to be in line with the new reforms. The medical field is not as prestigious; hence there is a need for motivation in the managerial other employee structure. It is also essential to establish control when monitoring and to ensure accountability. Another aspect that can improve the healthcare system is improving the allocation of funds in the healthcare system. The currently available budget and low salaries for healthcare employees are inadequate, which can improve work ethic. There is a need for financial support and the government's serious approach to health system development in Kosovo. To boost the plans for Kosovo, it is crucial to develop a strategic document for the Healthcare Information System and create a database system that is to be owned by stakeholders. Both the healthcare and education system has experienced a lot of negative impacts long after the war is over. The Kosovo republic has however made reforms on how best to revive the educational system and this is a good step towards change.

\section{REFERENCES}

Buwa, Dragudi, and Hannu Vuori. (2007). Rebuilding a health care system: war, reconstruction and health care reforms in Kosovo. The European Journal of Public Health, 17(2), https:/ /erepo.uef.fi/bitstream/handle/123456789/10642/urn_isbn_978-952-61-06380 .pdf? sequence $=1 \&$ isAllowed $=y$

Cardozo, Barbara Lopes, et al. (2000). Mental health, social functioning, and attitudes of Kosovar Albanians following the war in Kosovo. Jama 284(5), 569-577. https://jamanetwork.com/journals/jama/fullarticle/192943

European Union, pp. 9-9, Progress Report Reform of Teacher Education and Training, ec.europa.eu/education/sites/education/files/tt-report-xk.pdf.

Hossen, M. A., Zahir, E., Ata-E-Rabbi, H. M., Azam, M. A., and Rahman, M. H. (2021). Developing a Mobile Automated Medical Assistant for Hospitals in Bangladesh. 2021 IEEE World AI IoT Congress (AIIoT), 03660372, https:/ / doi.org/10.1109/ AIIoT52608.2021.9454236

John, John B., and Antonia Young. (2000). Kosovo. Encyclopædia Britannica, Encyclopædia Britannica, Inc., www.britannica.com/place/Kosovo

Llapi, Gjylbehare. "EDUCATION INTERRUPTED: KOSOVO 1980-1999." North Dakota State University.

Mustafa, Nehat, et al. (2011). Curriculum Framework for Pre-University Education in the Republic of Kosovo. The Ministry of Education, Science and Technology.

Nietsch, Julia. (2020). The Mother Teresa Society. Volunteer Work for the Kosovo-Albanian 'Parallel Structures' in the 1990s. Südosteuropa, 68(2), 200-224. https:/ /ideas.repec.org/a/bpj/soeuro/v68y2020i2p200-224n5.html

Nokhrin, I. M. (2021). ABKHAZ-GEORGIAN ETHNOPOLITICAL CONFLICT AS A COMPLEX CONFLICT AND PROSPECTS FOR ITS SETTLEMENT." Вестник удмуртского университета. Социология. Политология. Международные отношения, 5(1), 5764. https://www.internationalalert.org/wpcontent/uploads/2021/09/CaucasusGeorgia-Abkhazia-Intl-Engagement-EN-2010.pdf 
Picciano, Nicasia, and Arolda Elbasani. (2019). UN Shares Blame for Segregated Education in Kosovo. Balkan Insight.

Plesch, Valerie. (2015). A Painful Wait to Bury Kosovo's War Victims. Serbia News | Al Jazeera, Al Jazeera, www.aljazeera.com/features/2015/5/14/a-painful-wait-to-burykosovos-war-victims.

Pupovci, Dukagjin. (2013). Building New Realities for Teacher Training in Kosovo, dspace.epoka.edu.al/bitstream/handle/1/820/821-2406-1-

PB.pdf? sequence $=1 \&$ is Allowed $=y$.

Ragi, S., Rahman, M. H., Duckworth, J., Kalimuthu, J., Chundi P. and Gadhamshetty, V. (2021). Artificial Intelligence-driven Image Analysis of Bacterial Cells and Biofilms. ACM Transactions on Computational Biology and Bioinformatics, https:/ / doi.org/10.1109/TCBB.2021.3138304

Ramet, Sabrina P. (2020). Kosovo. World Book Student, World Book, www.worldbookonline.com/student/article?id=ar304560.

Shuey, Dean A., et al. (2003). Planning for health sector reform in post-conflict situations: Kosovo 1999-2000. Health Policy, 63(3),

299-310.

https:/ /vdoc.pub/documents/health-reforms-in-south-east-europe-1drb91kc0s10

Solana, Javier. (1999). NATO's Success in Kosovo. Foreign Affairs, 114-120. https:/ / www.foreignaffairs.com/articles/europe/1999-11-01/natos-success-kosovo

Steinhubl, Steven R., Evan D. Muse, and Eric J. Topol. (2013). Can mobile health technologies transform health care?. Jama 310(22), 2395-2396. https://www.scirp.org/(S(351jmbntvnsjt1aadkposzje))/reference/ReferencesPapers. aspx?ReferenceID=128435

The Editors of Encyclopaedia Britannica. (2020). Kosovo Conflict. Encyclopædia Britannica, Encyclopædia Britannica, Inc., www.britannica.com/event/Kosovo-conflict 
How to cite this article:

Han, A. E. (2021). Education and Healthcare Reforms in Post-Conflict Setting: Case Studies in Kosovo. Asian Journal of Humanity, Art and Literature, 8(2), 85-94. https://doi.org/10.18034/ajhal.v8i2.613

\section{Online Archive}

https://i-proclaim.my/journals/index.php/ajhal/issue/archive 